\title{
Manufacture of an automated prototype for corn tortilla cooking
}

\section{Manufactura de un prototipo automatizado para la cocción de tortilla de maiz}

\author{
GONZÁLEZ-MONZON, Ana Lilia†*, PIÑA-ALCANTARA, Henry Christopher and RUEDA- \\ MEDINA, Israel
}

ID 1 Autor: Ana Lilia, González-Monzon / DOI: 0000-0002-0280-0525, CVU CONACYT ID: 151293

ID $1^{\text {st }}$ Coautor: Henry Christopher, Piña-Alcantara / DOI: 0000-0001-5726-2915, CVU CONACYT ID: 719620

ID $2^{\text {nd }}$ Coautor: Israel, Rueda-Medina / DOI: 0000-0003-0405-0913, CVU CONACYT ID: 153741

\section{Resumen}

En el presente trabajo de la manufactura de un prototipo automatizado para la cocción para la tortilla de maíz, que es una base de alimentación principalmente de la cocina mexicana, en donde el proceso elaboración se realiza manualmente de manera artesanal por personas que prensan la masa para formar la tortilla la ponen en el comal y durante el proceso de cocción son volteadas de forma manual y utilizando un promedio de 3 tiempo. Por lo tanto, el objetivo fue realizar un prototipo de tres comales giratorios para la cocción de tortilla artesanal para automatizar el proceso de volteado y cocción de la tortilla para la transformación de la materia prima (masa). con el cual se puede programar la temperatura en un rango de $240^{\circ} \mathrm{C}-260^{\circ} \mathrm{C}$ con gas $\mathrm{LP}$, sin que las personas tengan que voltear la tortilla y de esta forma utilizar menor tiempo y obtener más producción y solo una persona opera los quemadores, pero también se tiene un gran ahorro en el consumo de gas. Para realizar la manufactura y automatización se utilizaron tres disciplinas importantes de la carrera de mecatrónica las cuales son: mecánica, electrónica e informática. Coadyuvando en el proceso del mismo.

Automatización, Manufactura, Sistema

\begin{abstract}
In the present work of the manufacture of an automated prototype for cooking for corn tortillas, which is a food base mainly for Mexican cuisine, where the elaboration process is done manually by hand by people who press the dough to form the tortilla put on the griddle and during the cooking process they are turned manually and using an average of 3 times. Therefore, the objective was to make a prototype of three rotating comals for the cooking of handmade tortillas to automate the process of turning and cooking the tortilla for the transformation of the raw material (dough). with which the temperature can be programmed in a range of $240{ }^{\circ} \mathrm{C}-260^{\circ} \mathrm{C}$ with LP gas, without people having to turn the tortilla and thus use less time and obtain more production and only one person operates the burners, but you also have great savings in gas consumption. To carry out manufacturing and automation, three important disciplines of the mechatronics career were used, which are: mechanical, electronic and computer science. Helping in its process.
\end{abstract}

Automátion, Manufacture, System

Citation: GONZÁLEZ-MONZON, Ana Lilia, PIÑA-ALCANTARA, Henry Christopher and RUEDA-MEDINA, Israel. Manufacture of an automated prototype for corn tortilla cooking. Rinoe Journal-Industrial Organization. 2019. 3-5: 18-23

\footnotetext{
*Correspondence to Author (mtra.analilia@tesji.com.edu)

$\dagger$ Researcher contributing first author.
} 


\section{Introduction}

Since historic times the corn tortilla in Mexican cuisine is a very important food base, in the State of Mexico in the municipality of Soyaniquilpan it still has the so-called tortillerías de comal (Calderón, A. E. 2019). As a raw material, the base is the mass of nixtamal where it is transformed by means of a press or totally by hand, its cooking is by means of a comal either with firewood or with LP gas. This process is called artisanal. With the manufacture of an automated prototype for cooking corn tortillas, the process helps to be more effective in its productivity.

Within the contents of this work, systems, automation and manufacturing are the first part of the background as the basis for technological innovation and development of the project's generalities. The second part is where he describes the livelihood of the work that includes software and hardware with the Arduino electronic platform (Reyes 2016). In the third part, the methodology used for the design and manufacture of the prototype for cooking the tortilla, which subsequently describes the steps to follow for the construction process. In the fourth part as final, there is the operation and testing of the automated machine for cooking the handmade corn tortilla, as the fifth and final conclusions of the results obtained from the prototype.

\section{Systems}

These are the computer programs that make it possible to execute specific tasks within a computer. For example, operating systems, applications, web browsers, games or programs such as Word, Excel and PowerPoint, Solidworks, Arduino. These features always work hand in hand. While the software provides the operations, the hardware is the physical channel through which this function can be performed.

\section{Automatization}

Industrial automation, considered as the management of information in companies for decision making in real time, incorporates computer science and automated control for the autonomous execution and optimally of processes designed according to engineering criteria and in line with the business management plans (DNP, Colciencias.
Strategic Plan of the National Program for Industrial Technological Development and Quality, 2000-2010).

Human logical procedures are entrusted to automated machines which process information much faster than man, with the help of mathematical models that describe both the technology itself and the human analytical and regulatory activity. It is the presence of automatic management systems in technological processes that ensure its optimization without the direct intervention of man. Production thus acquires the appearance of an automatic cycle that can be quickly and efficiently restructured.

\section{Manufacture}

A manufacturing is an industrial product, it is the transformation of raw materials into a fully finished product that is already in a position to be sold, that is, it is quoted in the corresponding market, in the distribution of manufactures it is in charge of the area of company offices. The word is linked to the concept of hand because precisely in the most remote past, manufacturing was produced by manual means, that is, by hands. (Miranda 2018).

\section{Arduino electronic platform}

Arduino is an open source electronics creation platform, which is based on free, flexible and easy-to-use hardware and software for creators and developers. This platform allows to create different types of microcomputers of a single plate to which the creator community can give them different types of use. (Reyes 2016).

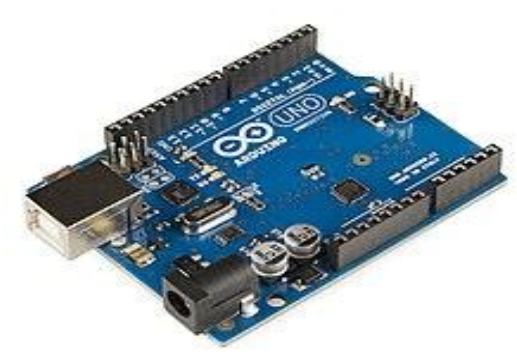

Figure 1 Arduino

\section{Methodology}

As part of the knowledge necessary to manage the activities associated with development, a methodology was applied to achieve the ideal project time. 
It consists of four phases

- $\quad$ Preliminary, which allows to gather the necessary information to establish the design framework.

- Basic design, analysis and optimization

- Prototype manufacturing and construction

Programming controlled by an arduino with secondary elements.

The method is to determine the physics equations that model the kinematic structure behavior. Once the kinematics model is obtained, it is evaluated in simulation in order to ensure its definition. In this way, the kinematic parameters are evaluated and by computer simulation. The next step of this methodology is to design and build the systems. In this part, it is usually possible to perform the control design.

\section{Mechanical design}

The design of the final fall of the tortilla will be coupled to the third lower comal where it has the functionality to have the fall, to accommodate them and to be able to remove them without any problem of disassembling it to carry out the looting to weigh it and make the sale and thus avoid more work for the personnel that will be working for the operation of the machine see (figure 2).

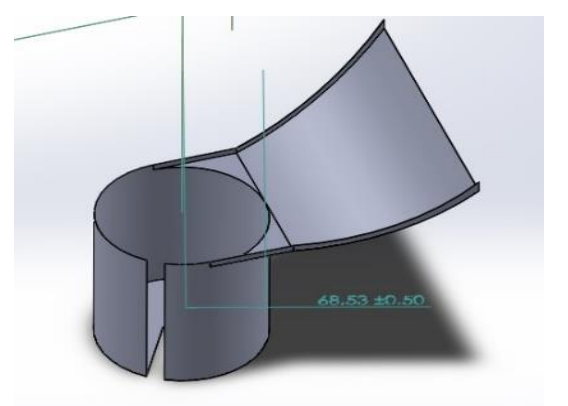

Figure 2 Caída de tortillas

In the transmission of force, the smaller gear wheel was contemplated, which is consistent with the larger gear wheel, where how many teeth the smaller gear wheel related to the revolutions of the reduction motor were calculated. (see figure 3 ).

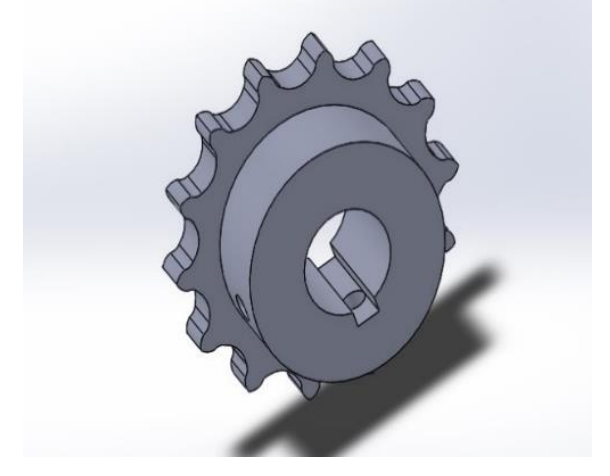

Figure 3 Mesh

To draw the relationships of how long it takes to make a $360^{\circ}$ turn as shown in the following formula see (table 1).

\begin{tabular}{|lr|}
\hline $\begin{array}{l}\text { Piñón }=14 \\
\text { vueltas }\end{array}$ & \multicolumn{2}{c|}{28} \\
28 vineltas & $60 \mathrm{~s}$ \\
Engrane $=74$ & $\frac{28}{60}=0.46 s$ \\
$\frac{14}{74}=0.1897 * 0.46 s$ & \\
\hline
\end{tabular}

Table 1 Formula

The design of the four lower bars to support the weight of all the components and have greater stability where 4 are seen in the lower part and 4 in the upper part. Upper and lower bars with averages of length $86 \mathrm{~cm}$, width of $5 \mathrm{~cm}$ and $7.6 \mathrm{~cm}$ high where 4 were used for the top and 4 at the bottom to have greater stability in the structure and strength. The four bottom bars to support the weight of all the components and have greater stability where 4 are seen at the bottom and 4 at the top. See (figure 4).

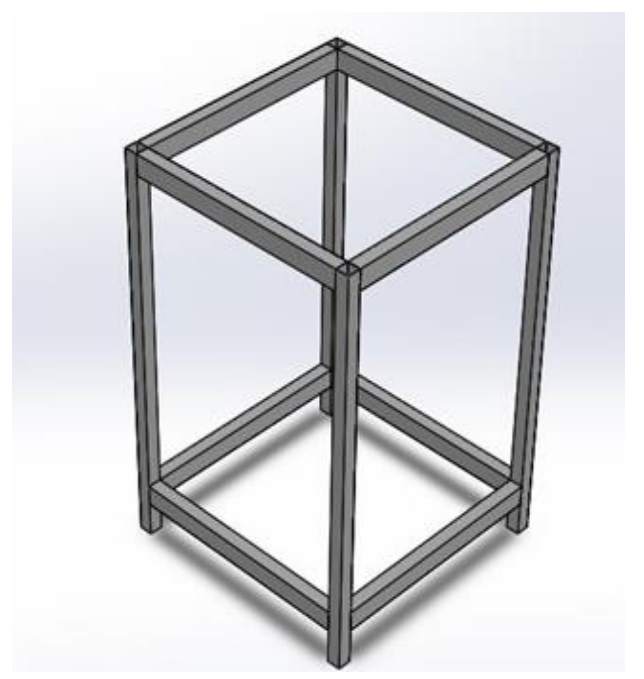

Figure 4 Barras inferiores 
In the lower and upper, the support bars for the bearing blocks were assembled to load the entire weight of the hooks and the comals where you will have the freedom to rotate $360^{\circ}$. See (figure 4).

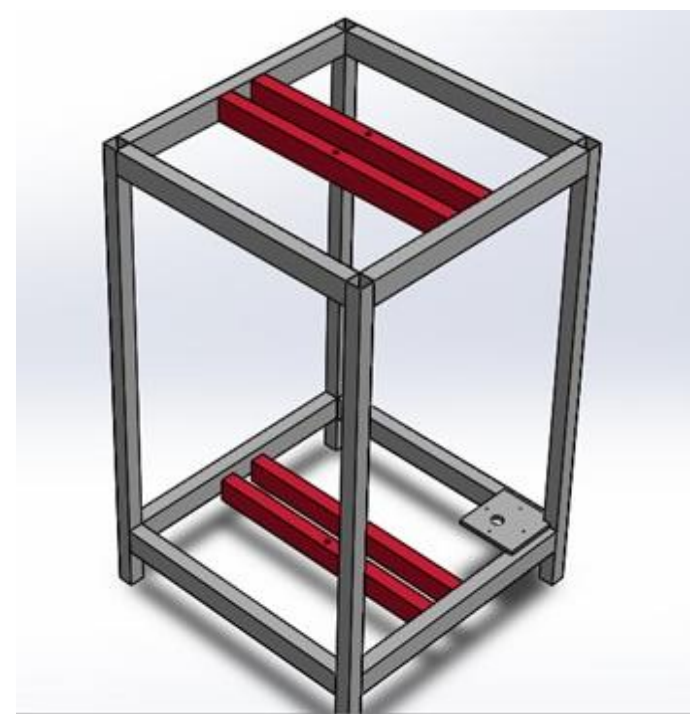

Figure 5 Barras superiores

For the rotation of the arrow, load bearings were assembled to support what the comals are and for the translation wheels were assembled for ease of movement.

The circular burners under each grid for the temperature of the tortillas placing one burner for each grid considering the space between each grid. See (figure 6).

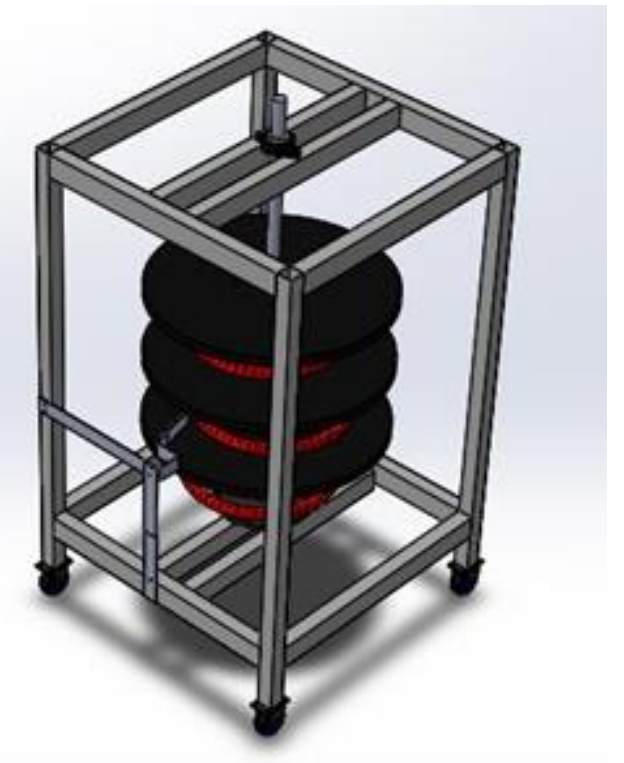

Figure 6 Prototype

\section{Control Design}

\section{Chain drive}

The main mission of cargo chains is to transmit high levels of effort. For this, the gear system was used due to having a larger section resistant than the normal transmission chains by the gearmotor and avoiding oscillations between the transmission system for them a gearing of 74 teeth was used a diametral passage 40 where it was assembled in the bottom of the arrow and the structure.

\section{Gearmotor}

Direct current gearmotor of 150 volts of $1 / 8 \mathrm{HP}$ with 28 revolutions per minute was used. An electric motor has a certain power in HP and has a certain operating speed at which the output arrow rotates, for example 1800 Revolutions per Minute (RPM). These two characteristics: Speed and Power have a certain "torque" or "torque" that the engine can release. It is precisely the "pair" that will allow us to rotate a certain load or not, the higher the "pair" the larger the load we can rotate. How fast we can do it will depend on the power of the gearmotor. The two characteristics are interrelated and depend on each other.

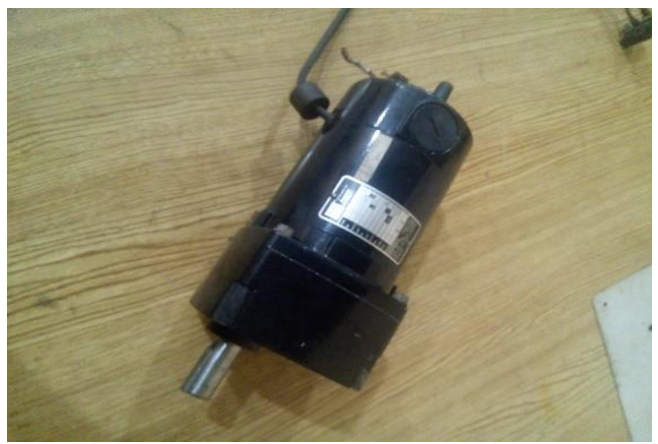

Figure 7 Motorreductor

\section{Volt relays}

A relay is a switch that can be activated by an electrical signal. In its simplest version it is a small electro-magnet that, when excited, moves the position of an electrical contact from connected to disconnected or vice versa. (Administer 2015). 


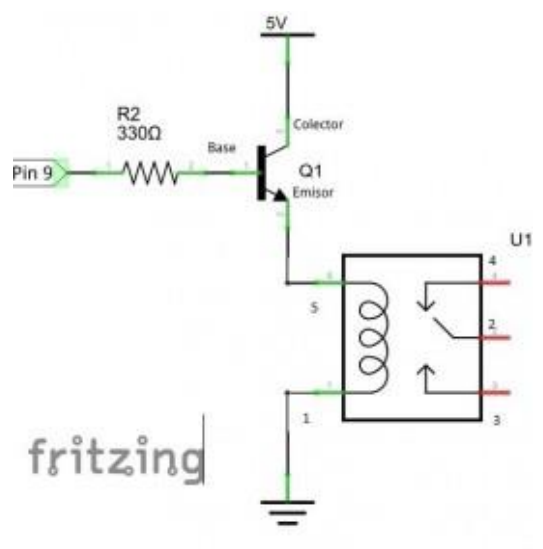

Figure 8 Circuito relevador

\section{Thermometers}

The $\mathrm{K}$ thermocouple temperature sensors with Max6675 model that are easy to use for programming, which were placed in the first comal to verify the temperature if it is correct for cooking the tortilla where the data will be displayed on an LCD screen.

First, the objective of this practice is to verify the functionality of the pressure sensor. The force becomes a change of resistance, as a result we vary the intensity of an LED. This intensity is finally dependent on the pressure in the sensor.

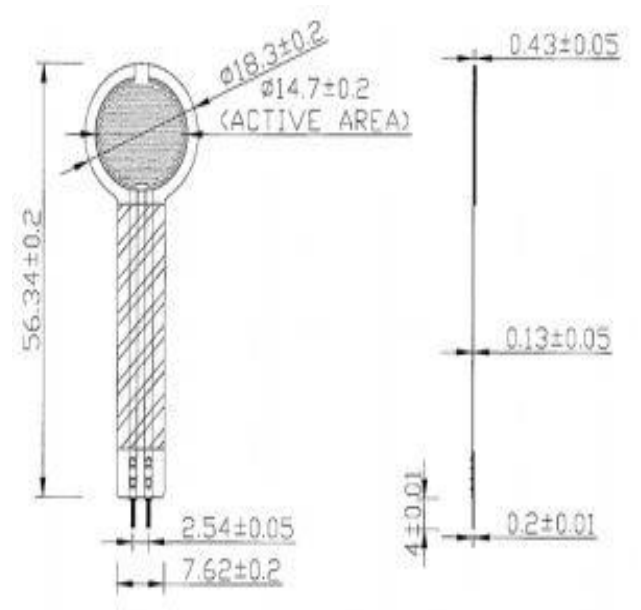

Figure 9 Características sensor MF01

\section{Programming}

In the programming stage the arduino MEGA was used for its versatility and ease of programming the machine, it is a free-use platform in terms of software and hardware. The relay code to execute in the arduino program is shown to be able to control the gearmotor and that is done through steps to complete the cooking of the corn tortilla.

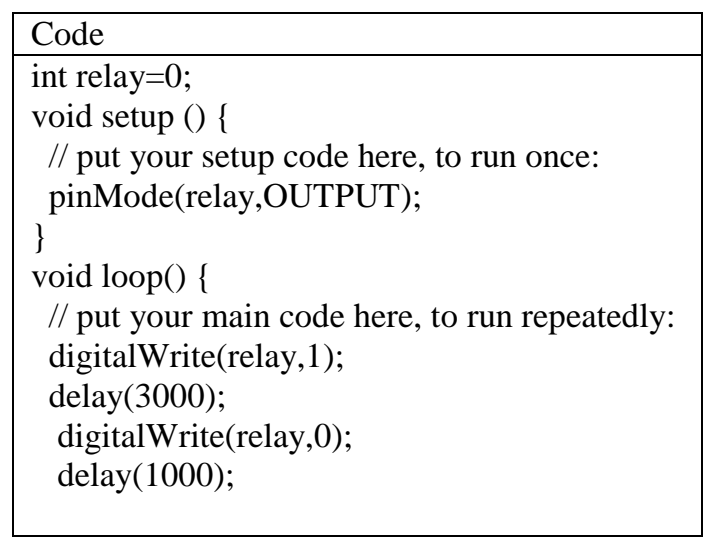

Table 2 Arduino code gearmotor control

\section{Results}

The foregoing meets the objective of facilitating the process of making corn tortillas by hand, with the manufacture of the prototype with the function of the mechanical and electrical where it turns mechanically for cooking and thus repeats turn two times to finish the process of cooking the tortilla, by means of an arduino it was programmed together with a thermocouple that has the function of detecting the temperature of the comals to establish in a range of $240^{\circ} \mathrm{C}$ $260^{\circ} \mathrm{C}$, shown in a display also with an infrared sensor to count along with the electric force floor sensor that will send the reading when in the basket weighing a kilo and how many pieces are, in the same way how many are made per hour. automation according to the above results in time savings, increased production, savings as gas L.P. and also avoid burn accidents in tortillas. (see image 2).

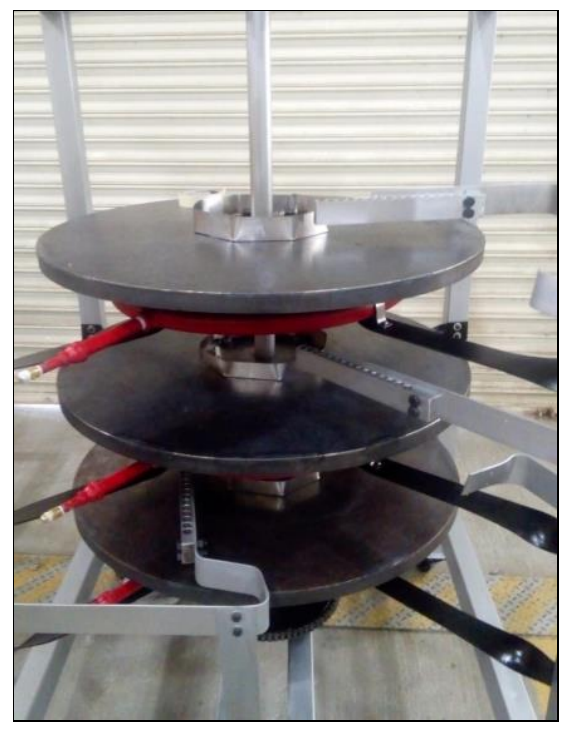

Figure 10 Prototype 


\section{Conclusions}

The importance of this prototype contribute to the integration of the different areas by integrating the interdisciplinarity of the mechatronic career, (Mechanics, Electronics, and Computer Science), since they are an important part for the development of the functional prototype to offer competitiveness in the tortilla industry, handmade since it is not a market very often in the field of automation, so it is important to venture into the development of this product.

Considering that it is a high-consumption food in Mexico, this is why with the manufacture of the arduino control rotary grid that uses different sensors and devices that programmed throw the temperature control and by means of a thermocouple the kilos produced and activation automation of turning, without leaving aside the energetic used as it is the LP gas that today has a high cost so that its consumption was reduced in great quantity, without leaving aside the workforce the risks and the load of work

Therefore, an automated comal for any type of business dedicated to artisanal tortillas has the benefit of energy savings, greater productivity and lower accident rates.

\section{Acknowledgments}

We thank the Technological of Higher Studies of Jilotepec for the sponsorship, support and facilities granted to participate in this congress.

Also to the department of mechatronics for all the support granted for the conclusion of this prototype.

\section{References}

Camacho L. M.A.(2003) Mecánica . Obtenido de Integración en Ingeniería Mecanica. https://dcbi.azc.uam.mx/media/Mecanica/PPI028-18PT E3.pdf

Edminister J. A. (1971), Circuitos electrónicos McGraw-Hill Interamericana de España.

Gaviria Arbeláez, C. (2019). Arepas colombianas: técnicas profesionales de cocina. Universidad de La Sabana Colombia.
Gutiérrez, M. O., Macías, A. S., Pugliese, V. A., \& Cerda, M. L. M. (2017) Del molino artesanal a la industria de la tortilla: Grupo IGOPE. el papel de las empresas locales en el desarrollo regional de México.

Hermosa D.A. (2012), Principios de electricidad y electrónica I, México D.F. Alfa omega.

Morales E.F., Sucar L.E. (2005) Los robots del futuro y su importancia para México, Ciudad de México, INAOE.

Miranda. A. (2018). Especialistas en la industria del maiz y de la tortilla. Obtenido Especialistas en la industria del maiz y de tortilla.

https://www.especializadosmiranda.com/

Marcelo, A. L. C., Bordi, I. V., Espinoza-Ortega, A., \& Calderón, A. E. (2019). Tortillas artesanales mazahuas y biodiversidad del maíz nativo. Reflexiones desde el ecofeminismo de la subsistencia. Sociedad y Ambiente, (19), 265291.

Miranda-García, J. (2019). Mercadotecnia de servicios aplicada a una empresa familiar. Caso: molino de nixtamal Doña Meche.

Ortiz, J. C. (2015). Máquina tortilladora para pruebas de laboratorio. http://www.itcelaya.edu.mx/ojs/in dex.php/pistas/article/viewFile/324/313

Reyes C.F. (2016), Arduino aplicaciones en robótica, mecatrónica e ingenierías, México D.F. alfa omega. 